\title{
ANALISIS GAMBAR DIGITAL SEBAGAI METODE KARAKTERISASI DAN KUANTIFIKASI WARNA PADA IKAN HIAS
}

\author{
Ruby Vidia Kusumah*), Eni Kusrini*), Siti Murniasih*), Anjang Bangun Prasetio*, \\ dan Kamaluddin Mahfudz**) \\ ") Balai Riset Budidaya Ikan Hias \\ Jl. Perikanan No. 13, Pancoran Mas, Depok, Jawa Barat \\ E-mail: kusumah_rv@yahoo.com \\ *) Departemen Ilmu Komputer, Institut Pertanian Bogor \\ Jl. Meranti, Kampus IPB Darmaga, Bogor
}

(Naskah diterima: 26 Agustus 2011; Disetujui publikasi: 28 Oktober 2011)

\begin{abstract}
ABSTRAK
Analisis gambar (foto) digital digunakan sebagai metode alternatif karakterisasi dan kuantifikasi warna yang obyektif, akurat, serta aplikatif. Software Image membantu mengukur dan mengelompokkan beberapa parameter kualitatif warna secara kuantitatif berdasarkan standar nilai digital RGB (Red Green Blue) yang dimiliki setiap pikselnya. Dengan melakukan konversi ke model HSB (Hue Saturation Brightness), nilai digital warna yang diperoleh semakin mudah dipahami sesuai konsep cara pandang mata manusia. Frekuensi serta distribusi warna yang terukur pun dapat ditampilkan dalam bentuk histogram dua dimensi dan grafik tiga dimensi warna (3D color space). Hasil analisis pada delapan strain warna ikan cupang hias (Betta splendens) menunjukkan variasi warna yang ditampilkan dalam bentuk kisaran (minimum- maksimum), rata- rata (mean), serta standar deviasi (SD) dari setiap nilai RGB dan HSB. Kecerahan setiap individu dalam suatu strain warna diukur berdasarkan nilai kecerahan (brightness) yang dimiliki model warna HSB. Penelitian ini merupakan studi pendahuluan yang bertujuan untuk mempelajari analisis gambar digital sebagai metode karakterisasi dan kuantifikasi warna pada ikan hias.
\end{abstract}

KATA KUNCl: Betta splendens, gambar digital, ikan hias, karakterisasi, kuantifikasi

ABSTRACT: Digital image analysis as the tool in color characterization and quantification of ornamental fish. By: Ruby Vidia Kusumah, Eni Kusrini, Siti Murniasih, Anjang Bangun Prasetio, and Kamaluddin Mahfudz

Digital imaging analysis has been used as an alternative method of color characterization and quantification which are objective, accurate, and applicative. ImageJ software helps to quantitatively measure and group several qualitative parameters base on digital values of RGB (Red Green Blue) from each pixels. By converting to HSB (Hue Saturation Brightness) model, the data can be more easily to understood which is similar to concept on how human eyes look at an object. The frequencies and distributions of colors can be also presented in form of histogram and $3 D$ color graphics. The analysis of eight color strains of siamese fighting fish (Betta splendens) showed color variation depicted in form of ranges (minimummaximum), means, and standard deviation (SD) of each RGB (Red Green Blue), and HSB (Hue Saturation Brightness) values. The lightness of each individual color strain was quantified based on the brightness values of HSB. This result is a preliminary 
baseline data to better develop digital image analysis as the tool of characterization and quantification of colors on ornamental fish.

\section{KEYWORDS: Betta splendens, characterization, color, digital images, ImageJ, HSB, method, ornamental fish, quantification, RGB, siamese fighting fish, software}

\section{PENDAHULUAN}

Warna merupakan karakter komersial penting yang dapat mempengaruhi tingkat penerimaan konsumen terhadap suatu produk hewani sehingga turut menentukan nilai jual produk tersebut di pasar (Colihueque, 2010; Tume et al., 2009; Pavlidis et al., 2006; Anderson, 2000). Pada ikan salmon, warna menjadi parameter yang pertama kali dipertimbangkan konsumen untuk pendugaan spesies, umur, asal, harga, rasa/tekstur yang diinginkan, kesegaran, serta kualitas produk (Anderson, 2000). Sedangkan pada banyak spesies ikan hias, misalnya cupang hias (Betta splendens), warna dikenal sebagai salah satu karakter penentu keindahan, karena ikan cupang hias merupakan salah satu ikan hias yang paling banyak ragam warnanya.

Dalam ilmu pengetahuan, warna yang menghiasi dan memberikan corak pada tubuh hewan telah lama menjadi topik penting dan menarik perhatian para ahli biologi (Leclercq et al., 2009). Bahkan Aristoteles (384- 322 SM) dalam bukunya yang berjudul Historia Animalium pun pernah menuliskan beberapa hasil pengamatannya terhadap warna serta perubahan warna yang terjadi pada beberapa spesies hewan, seperti lobster; sotong; dan cumi- cumi (Thompson, 1910). Sampai sekarang, berbagai penelitian yang menyangkut warna serta kualitas warna semakin berkembang dan banyak dilakukan dalam berbagai studi mulai dari taksonomi (Byers, 2006; Pavlidis et al., 2006; Chapman \& Fitz-Coy dalam Yasir \& Qin, 2009), genetika kuantitatif (David et al., 2004; Hoekstra, 2006), tingkah laku hewan (etologi) (Korzan et al., 2008; Price et al., 2008), biologi perkembangan (Hoekstra, 2006), evolusi (Hoekstra, 2006; Hofreiter \& Schoneberg, 2010), kesehatan hewan (Clotfelter et al., 2007), fisiologi (Szisch et al., 2002; Yasir \& Qin, 2009), hingga nutrisi (Booth et al., 2004; Kalinowski et al., 2005).

Meskipun telah lama menjadi karakter penting dan menarik untuk dipelajari, namun metode standar karakterisasi dan kuantifikasi warna pada hewan masih menjadi kendala bagi banyak pengguna, termasuk di antaranya adalah peneliti. Warna yang tampak secara visual seringkali sulit dikarakterisasi dan dikuantifikasi pada suatu standar nilai tertentu. Akibatnya, hasil yang diperoleh pun seringkali tidak akurat karena perbedaan persepsi yang terjadi antara pengamat satu dengan lainnya (subyektif).

Observasi langsung secara visual merupakan salah satu metode karakterisasi dan kuantifikasi warna pada makhluk hidup, khususnya ikan hias. Meskipun memberikan hasil yang subyektif dan tidak akurat, namun metode ini masih banyak digunakan dalam berbagai studi yang menyangkut warna serta kualitas warna, contoh fisiologi, dan nutrisi (Ako et al., 1999). Spektrofotometer dan colorimeter dapat digunakan sebagai metode lainnya yang lebih dipercaya, obyektif, serta akurat dalam karakterisasi dan kuantifikasi warna. Harga alat yang mahal, luas area tangkapan yang sempit (2-10 $\left.\mathrm{mm}^{2}\right)$, serta fungsi yang terbatas untuk aplikasi langsung pada hewan liar di alam menjadi kelemahan dari kedua metode ini.

Pesatnya perkembangan teknologi dalam bidang elektronik telah sukses menghasilkan produk kamera digital yang semakin konsisten dan akurat dalam mengabadikan berbagai obyek serta warna sesuai dengan apa yang terlihat dan tertangkap secara visual oleh mata. Dengan bantuan perangkat lunak (software) seperti ImageJ, produk berupa gambar (foto) digital yang dihasilkanpun dapat digunakan sebagai metode alternatif karakterisasi dan kuantifikasi warna yang obyektif, akurat, aplikatif, serta murah. Beberapa parameter kualitatif warna dapat diukur dan dikelompokkan secara kuantitatif berdasarkan standar nilai digital RGB (Red Green Blue) yang dimiliki setiap piksel- nya. Dengan melakukan konversi ke model HSB (Hue Saturation Brightness), nilai digital warna yang diperoleh semakin mudah dipahami sesuai konsep cara pandang mata manusia. Penelitian ini merupakan studi pendahuluan analisis gambar digital sebagai metode karakterisasi dan kuantifikasi warna pada ikan hias. 


\section{BAHAN DAN METODE}

\section{Objek Penelitian}

Delapan strain warna ikan cupang hias (Betta splendens Regan 1910) dipilih sebagai perwakilan dari setiap warna yang umum dijumpai pada banyak spesies ikan hias air tawar ataupun laut. Adapun strain warna yang dimaksud antara lain terdiri atas merah, kuning, jingga, cyan, biru (royal blue), putih (opaque), hitam (super black), abu (Gambar 1). Jumlah sampel yang digunakan sebanyak 91 ekor dengan beberapa strain warna, yaitu: cyan $(9$ ekor), abu- abu (6 ekor), putih (6 ekor), biru (18 ekor), merah (14 ekor), jingga (10 ekor), kuning (19 ekor), dan hitam (9 ekor). Secara terperinci dapat dilihat pada Tabel 1 dan 2.

\section{Teknik Pengambilan Foto (Gambar Digital)}

Setiap objek penelitian difoto dalam akuarium berukuran $15 \mathrm{~cm} \times 5 \mathrm{~cm} \times 20 \mathrm{~cm}$ menggunakan kamera digital Olympus E450 DSLR tanpa dilakukan pembiusan. Foto diambil dalam ruang gelap (studio) sebagai upaya standarisasi terhadap fluktuasi cahaya. Pencahayaan bersumber dari lampu neon 40 watt yang diletakkan di bagian depan atas akuarium. Pengambilan foto dilakukan pada jarak $10 \mathrm{~cm}$ di depan akuarium. Foto (gambar) digital yang dihasilkan disimpan dalam format JPG.

\section{Analisis Warna}

Foto (gambar) digital dari setiap strain warna ikan cupang hias dianalisis menggunakan software ImageJ 1.440 (Wayne Rasband, National Institut Institutes of Health, USA) dengan tambahan plugin Color Inspector 3D (Barthel, 2007) untuk menampilkan grafis tiga dimensi warna. Software dan plugin dapat diunduh secara gratis dari alamat http:/ / rsb.info.nih.gov. Beberapa parameter warna yang diperoleh dari aplikasi ini antara lain terdiri atas rata- rata (mean), jumlah dan frekuensi, serta grafis distribusi setiap nilai digital RGB (Red Green Blue) berupa gambar dua dimensi dan tiga dimensi. Persentase setiap nilai $R, G$, dan $\mathrm{B}$ dihitung menggunakan rumus: $\%=$ (meanR/ (meanR+meanG +meanB)) x100\% $\% G$ dan \%B diperoleh dengan cara yang sama. Nilai mean RGB dikonversi pada model warna HSB (Hue Saturation Brightness) menggunakan RGB to HSB Calculator (http:// www.rags-intinc.com/ PhotoTechStuff/ AcrCalibration/ RGB2HSB.html). Sedangkan bagian badan ikan cupang (Betta splendens) yang dianalisis antara lain terdiri atas warna badan (Bd) dan sirip ekor (Se). Khusus untuk analisis kualitas warna, juga ditambahkan warna
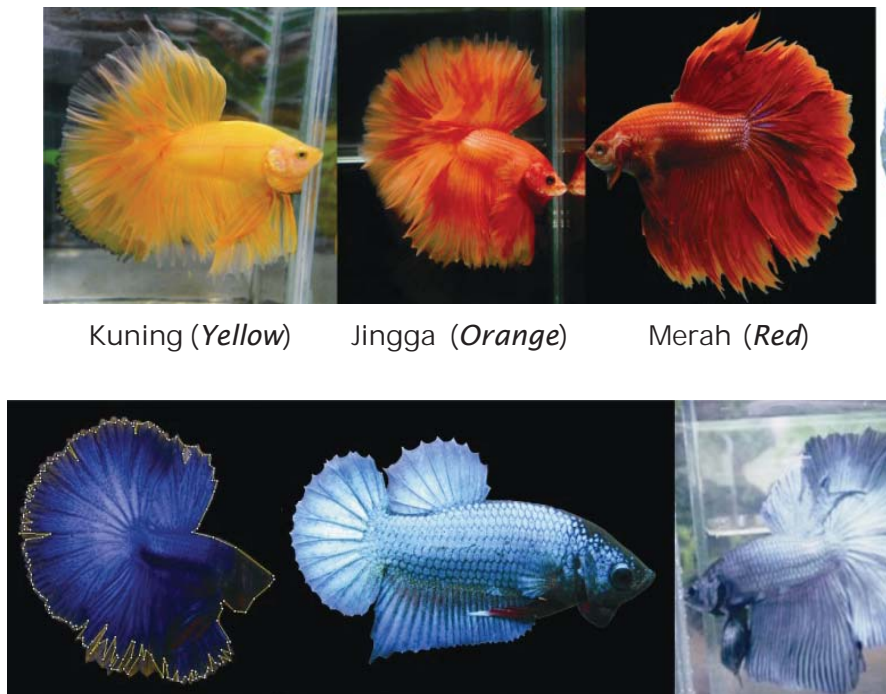

Biru (Blue)
Biru muda (Cyan)

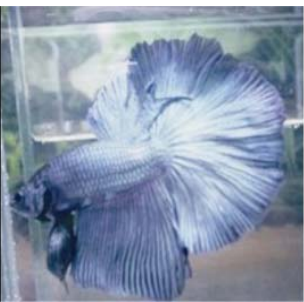

Abu- abu (Grey)

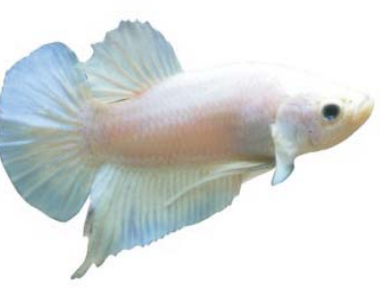

Putih (White)

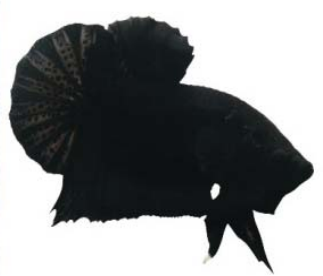

Hitam (Black)

Gambar 1. Strain warna pada cupang hias (Betta splendens)

Figure 1. Betta splendens color strains 
HSB pada sirip perut (Sp). Sedangkan perbandingan karakter warna untuk merah, hijau, dan biru bagian badan dan sirip ekor untuk setiap strain warna ikan cupang hias dapat dilihat pada Gambar 2.

\section{Analisis Statistika}

Perbedaan kualitas warna pada badan $(\mathrm{Bd})$, sirip ekor (Se), dan sirip perut $(\mathrm{Sp})$ dianalisis berdasarkan model warna HSB. Nilai digital warna $\mathrm{H}$ (Hue), S (Saturation), dan B (Kecerahan) yang diperoleh selanjutnya dianalisis statistik menggunakan uji ANOVA dengan software Microsoft Excel 2007.
Sebagai contoh, analisis statistika dilakukan pada strain cupang warna biru.

\section{HASIL DAN BAHASAN}

\section{Karakter Setiap Strain Warna Ikan Cupang Hias}

\section{Model RGB}

Setiap strain warna ikan cupang dikarakterisasi dalam bentuk kisaran, rata- rata (mean), dan persentase nilai digital RGB (Red Green Blue) pada badan (Bd) dan sirip ekor (Se). Cupang cyan memiliki komponen

Tabel 1. Nilai digital warna pada badan (Bd) dan sirip ekor (Se) berdasarkan model RGB (Red Green Blue)

Table 1. Digital value of body and caudal fin color based on RGB model (Red Green Blue)

\begin{tabular}{|c|c|c|c|c|c|c|c|c|}
\hline \multirow{2}{*}{$\begin{array}{l}\text { Strain warna } \\
\text { Color strain }\end{array}$} & \multirow{2}{*}{$\mathbf{N}$} & \multirow{2}{*}{$\begin{array}{c}\text { Keterangan } \\
\text { Remark }\end{array}$} & \multicolumn{3}{|c|}{ Badan (Body) } & \multicolumn{3}{|c|}{ Sirip ekor (Caudal fin) } \\
\hline & & & $\mathbf{R}$ & G & B & $\mathbf{R}$ & G & B \\
\hline Cyan & & Kisaran & $38-106$ & $130-224$ & $193-241$ & $35-92$ & $136-211$ & $182-244$ \\
\hline \multirow[t]{2}{*}{ Cyan } & 9 & Mean $\pm S D$ & $64 \pm 22$ & $173+29$ & $222 \pm 19$ & $64 \pm 18$ & $162 \pm 23$ & $213 \pm 20$ \\
\hline & & $\%$ Mean & 14 & 38 & 48 & 15 & 37 & 49 \\
\hline Abu & & Kisaran & $61-137$ & $61-159$ & $83-187$ & $111-179$ & $136-197$ & $146-218$ \\
\hline \multirow[t]{2}{*}{ Gray } & 6 & Mean $\pm S D$ & $92 \pm 33$ & $99 \pm 37$ & $123 \pm 41$ & $139+29$ & $159 \pm 23$ & $183 \pm 26$ \\
\hline & & \%Mean & 29 & 32 & 39 & 29 & 33 & 38 \\
\hline Putih & & Kisaran & $176-214$ & $184-208$ & $192-229$ & $120-172$ & $145-190$ & $139-202$ \\
\hline \multirow[t]{2}{*}{ White } & 6 & $M e a n \pm S D$ & $196 \pm 15$ & $198 \pm 9$ & $213 \pm 13$ & $142 \pm 19$ & $169 \pm 20$ & $168 \pm 21$ \\
\hline & & $\%$ Mean & 32 & 33 & 35 & 30 & 35 & 35 \\
\hline Biru & & Kisaran & $4-101$ & $22-135$ & $73-226$ & $5-114$ & $43-165$ & $109-244$ \\
\hline \multirow[t]{2}{*}{ Blue } & 18 & $M e a n \pm S D$ & $41+27$ & $65 \pm 32$ & $160 \pm 48$ & $51 \pm 30$ & $95 \pm 42$ & $188 \pm 45$ \\
\hline & & $\%$ Mean & 15 & 24 & 60 & 15 & 28 & 56 \\
\hline Merah & & Kisaran & $128-249$ & $10-78$ & $9-68$ & $109-251$ & $2-88$ & $0-49$ \\
\hline \multirow[t]{2}{*}{ Red } & 14 & Mean $\pm S D$ & $181 \pm 40$ & $40 \pm 23$ & $33+21$ & $183 \pm 44$ & $30 \pm 21$ & $21 \pm 13$ \\
\hline & & $\%$ Mean & 71 & 16 & 13 & 78 & 13 & 9 \\
\hline Jingga & & Kisaran & $161-241$ & $54-162$ & $6-97$ & $138-232$ & $35-152$ & $6-87$ \\
\hline \multirow[t]{2}{*}{ Orange } & 10 & Mean $\pm S D$ & $202+29$ & $89 \pm 34$ & $40+29$ & $174 \pm 33$ & $82 \pm 35$ & $35+28$ \\
\hline & & $\%$ Mean & 61 & 27 & 12 & 60 & 28 & 12 \\
\hline Kuning & & Kisaran & $169-243$ & $129-207$ & 8-135 & $115-243$ & 108-198 & $8-124$ \\
\hline \multirow[t]{2}{*}{ Yellow } & 19 & $M e a n \pm S D$ & $222 \pm 19$ & $170 \pm 20$ & $68 \pm 41$ & $205 \pm 36$ & $155 \pm 23$ & $57 \pm 32$ \\
\hline & & $\%$ Mean & 48 & 37 & 15 & 49 & 37 & 14 \\
\hline Hitam & & Kisaran & $7-32$ & $5-31$ & $5-32$ & $7-46$ & $9-53$ & $7-62$ \\
\hline \multirow[t]{2}{*}{ Black } & 9 & Mean $\pm S D$ & $15 \pm 8$ & $15 \pm 8$ & $13 \pm 9$ & $25 \pm 13$ & $26 \pm 15$ & $27 \pm 20$ \\
\hline & & $\%$ Mean & 35 & 34 & 31 & 32 & 33 & 35 \\
\hline
\end{tabular}

$\mathrm{N}$ : jumlah sampel (total sampel); R: komponen warna merah pada nilai digital RGB (componen red color to digital value RGB); G: komponen warna digital hijau (componen green color digital); B: komponen warna digital biru (componen blue color digital); SD: standar deviasi (deviation standart) 
warna digital hijau (G) (Bd: 38\% Se: 37\%) dan biru (B) (Bd: 48\% Se: 49\%) yang dominan dibandingkan komponen warna merah (R) (Bd: 14\% Se: 15\%). Sedangkan cupang kuning memiliki komponen warna merah (R) (Bd: 48\% Se: $49 \%$ dan hijau (G) (Bd dan Se: 37\%) yang dominan. Cupang biru memiliki komponen warna digital biru (B) yang lebih dominan (Bd: 60\% Se: 56\% dibandingkan komponen warna lainnya (R dan G). Sedangkan cupang merah dan oranye memiliki komponen warna merah (R) yang dominan (merah: Bd: 71\% Se: 78\% oranye: Bd: $61 \%$ Se: $60 \%$. Pada cupang putih, abu, dan hitam, komponen- komponen warna yang dimiliki cenderung bernilai seimbang. Secara lengkap, karakter warna RGB setiap strain ikan cupang hias disajikan pada Tabel 1 dan Gambar 2.

\section{Model HSB}

Berdasarkan model warna HSB (Hue Saturation Brightness), karakter setiap strain warna ikan cupang (Gambar 3) disajikan dalam bentuk kisaran dan rata- rata (mean). Setiap strain warna menunjukkan komponen warna digital Hue $(\mathrm{H})$ yang spesifik mulai dari cupang merah (Bd: $0^{\circ}-9^{\circ}$; Se: $\left.0^{\circ}-12^{\circ}\right)$, oranye $\left(\mathrm{Bd}: 11^{\circ}-27^{\circ}\right.$; Se: $\left.11^{\circ}-37^{\circ}\right)$, kuning (Bd: $30^{\circ}-49^{\circ}$; Se: $30^{\circ}-54^{\circ}$, cyan (Bd: $186^{\circ}-206^{\circ}$ Se: $\left.187^{\circ}-208^{\circ}\right)$, abu (Bd: 208 ${ }^{\circ}-286^{\circ}$; Se: $190^{\circ}-268^{\circ}$ ), biru (Bd: $219^{\circ}-248^{\circ}$; Se: $\left.202^{\circ}-240^{\circ}\right)$, putih (Bd: $194^{\circ}-357^{\circ}$; Se: $129^{\circ}-$ 193), dan hitam (Bd: $0^{\circ}-300^{\circ}$; Se: $0^{\circ}-348^{\circ}$ ). Pada tahap selanjutnya, variasi warna juga ditentukan oleh tingkat kejenuhan (saturasi, S) dan kecerahan (brightness, B)- nya. Secara lengkap karakter warna HSB disajikan pada Tabel 2 dan Gambar 3.

\section{Perbandingan Warna}

\section{Antar Strain Warna}

\section{Hue}

Berdasarkan nilai mean hue $(\mathrm{H})$, selisih warna terbesar antara badan dan sirip ekor

Tabel 2. Nilai digital warna pada badan dan sirip ekor berdasarkan model HSB (Hue Saturation Brightness)

Table 2. Digital value of body and caudal fin color based on HSB model (Hue Saturation Brightness)

\begin{tabular}{|c|c|c|c|c|c|c|c|c|}
\hline \multirow{2}{*}{$\begin{array}{l}\text { Strain warna } \\
\text { Color strain }\end{array}$} & \multirow{2}{*}{$\mathbf{N}$} & \multirow{2}{*}{$\begin{array}{c}\text { Keterangan } \\
\text { Remark }\end{array}$} & \multicolumn{3}{|c|}{ Badan (Body) } & \multicolumn{3}{|c|}{ Sirip ekor (Caudal fin) } \\
\hline & & & $\mathbf{H}\left({ }^{\circ}\right)$ & S (\%) & B (\%) & $\mathbf{H}\left({ }^{\circ}\right)$ & S (\%) & B (\%) \\
\hline Cyan & \multirow{2}{*}{9} & Kisaran & $186-206$ & $56-80$ & $76-95$ & $187-208$ & $59-82$ & $71-96$ \\
\hline Cyan & & Mean $\pm S D$ & $198 \pm 7$ & $72 \pm 8$ & $87 \pm 7$ & $201 \pm 6$ & $70 \pm 7$ & $83 \pm 8$ \\
\hline Abu & \multirow{2}{*}{6} & Kisaran & $208-286$ & $22-38$ & $33-73$ & $190-268$ & $14-45$ & $57-85$ \\
\hline Gray & & Mean $\pm S D$ & $234 \pm 32$ & $30 \pm 6$ & $48 \pm 16$ & $221 \pm 31$ & $26 \pm 11$ & $72 \pm 10$ \\
\hline Putih & \multirow{2}{*}{6} & Kisaran & $194-357$ & $6-16$ & $81-90$ & 129-193 & $8-28$ & $57-79$ \\
\hline White & & Mean $\pm S D$ & $252 \pm 57$ & $12 \pm 4$ & $85 \pm 3$ & $168 \pm 28$ & $18 \pm 9$ & $68 \pm 8$ \\
\hline Biru & \multirow{2}{*}{18} & Kisaran & $219-248$ & $50-97$ & $29-89$ & $202-240$ & $49-95$ & $43-96$ \\
\hline Blue & & Mean $\pm S D$ & $229 \pm 8$ & $76 \pm 12$ & $63 \pm 19$ & $223 \pm 11$ & $74 \pm 13$ & $74 \pm 18$ \\
\hline Merah & \multirow{2}{*}{14} & Kisaran & $0-9$ & $66-94$ & $50-88$ & $0-12$ & $50-100$ & $43-98$ \\
\hline Red & & Mean $\pm S D$ & $3 \pm 3$ & $83 \pm 9$ & $68 \pm 14$ & $3 \pm 3$ & $87 \pm 12$ & $70 \pm 18$ \\
\hline Jingga & \multirow{2}{*}{10} & Kisaran & $11-27$ & $60-97$ & $63-95$ & $11-37$ & 55-97 & $54-91$ \\
\hline Orange & & Mean $\pm S D$ & $18 \pm 6$ & $81 \pm 13$ & $79 \pm 11$ & $21 \pm 7$ & $81 \pm 14$ & $69 \pm 13$ \\
\hline Kuning & \multirow{2}{*}{19} & Kisaran & $30-49$ & $38-96$ & $66-95$ & $30-54$ & $30-96$ & $45-95$ \\
\hline Yellow & & Mean $\pm S D$ & $39 \pm 5$ & $69 \pm 19$ & $87 \pm 7$ & $40 \pm 7$ & $71 \pm 18$ & $80 \pm 14$ \\
\hline Hitam & \multirow{2}{*}{9} & Kisaran & $0-300$ & 3- 58 & $3-13$ & $0-348$ & $5-54$ & 24-Apr \\
\hline Black & & Mean $\pm S D$ & $103 \pm 107$ & $29 \pm 17$ & $6 \pm 3$ & $167 \pm 124$ & $24 \pm 14$ & $12 \pm 7$ \\
\hline
\end{tabular}

$\mathrm{N}$ : jumlah sampel (total sample); H: jenis warna (hue) dalam model HSB (color kind (hue) in model); S: tingkat kejenuhan/ kemurnian warna (saturation); B: tingkat kecerahan warna (brightness); SD: standar deviasi (deviation standard) 

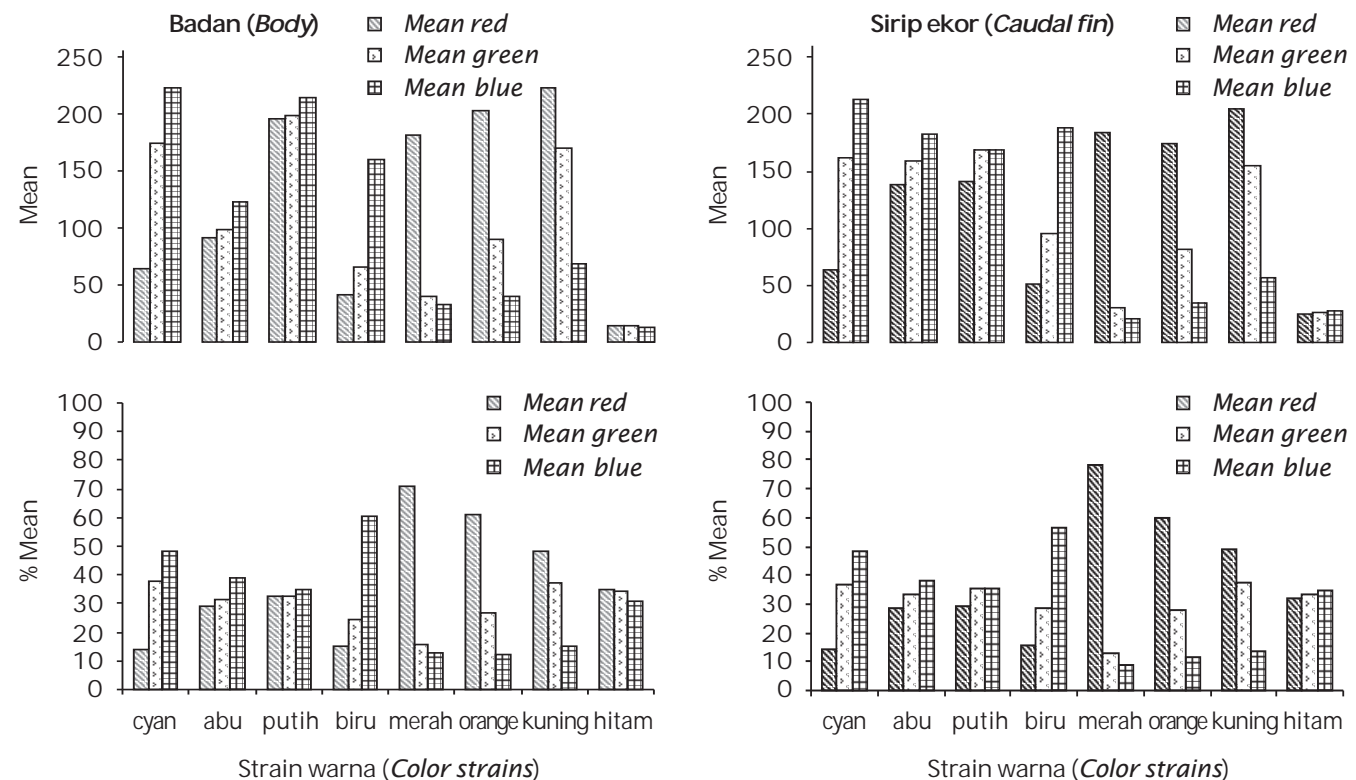

Gambar 2. Histogram perbandingan karakter warna RGB badan dan sirip ekor pada setiap strain warna ikan cupang hias (Betta splendens)

Figure 2. Histogram of RGB color character ratio of body and caudal fin of each color strain of Betta splendens
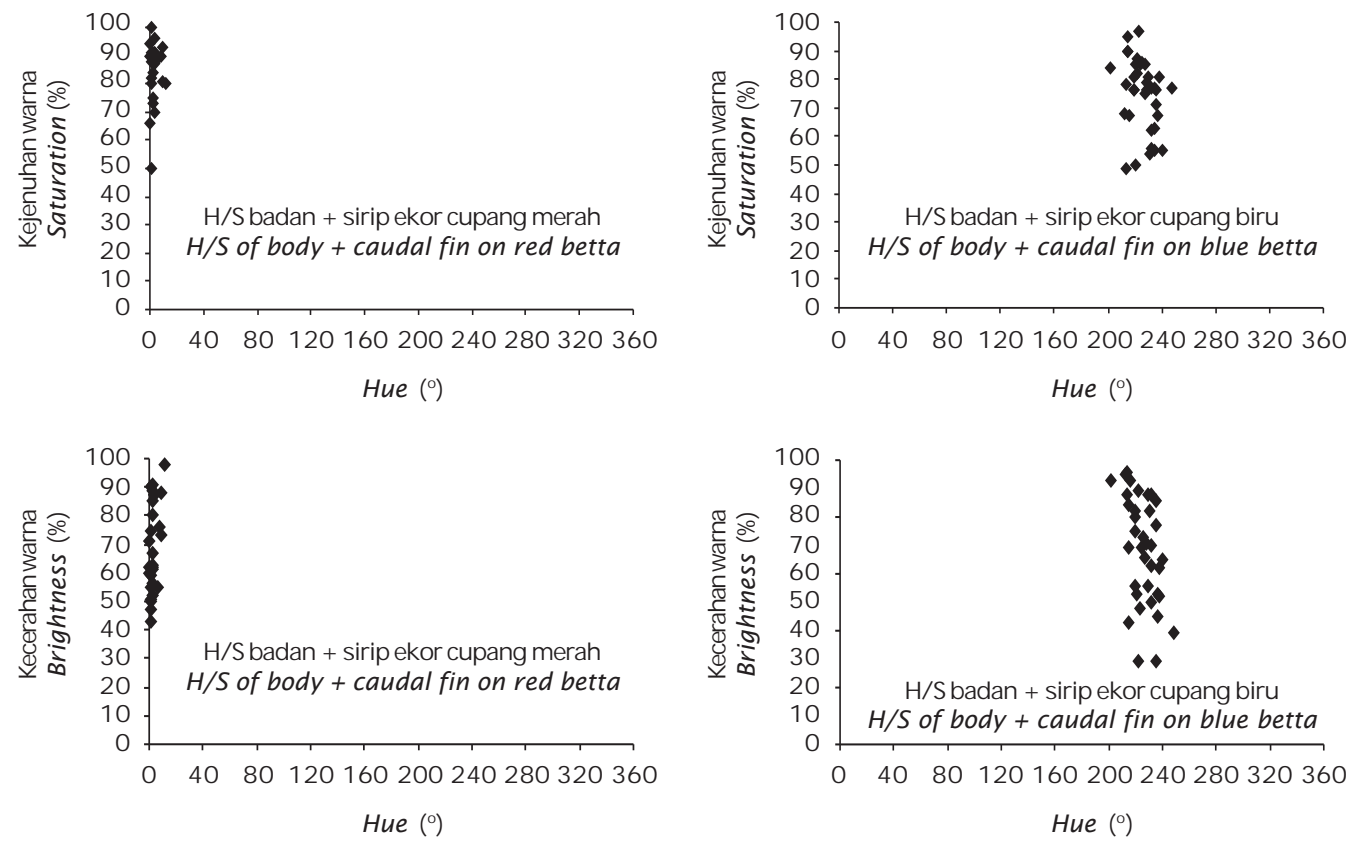

Gambar 3. Contoh distribusi tingkat kejenuhan (S) dan kecerahan (B) jenis warna (H) merah dan biru pada model HSB

Figure 3. Examples of saturation distribution $(S)$ and brightness $(B)$ hue $(H)$ red and blue on HSB model 
terdapat pada strain ikan cupang putih dan terkecil dimiliki strain warna kuning, sedangkan strain merah tidak terdapat perbedaan di antara kedua bagian tubuh tersebut (Tabel 2; Gambar 4A). Warna badan pada ikan cupang abu, putih, dan biru memiliki nilai lebih tinggi dibandingkan warna sirip ekornya. Sebaliknya pada ikan cupang cyan, jingga, kuning, dan hitam memiliki nilai lebih tinggi dibandingkan warna badannya (Gambar 4A).

\section{Saturasi}

Berdasarkan nilai mean saturation (S), selisih nilai antara warna badan dengan warna ekor setiap strain warna tidak begitu besar. Perbedaan terbesar dimiliki strain warna ikan putih dan terkecil terdapat pada strain cyan dan kuning, sedangkan pada strain orange tidak terdapat perbedaan di antara keduanya. Strain cyan, abu, biru, dan hitam memiliki warna
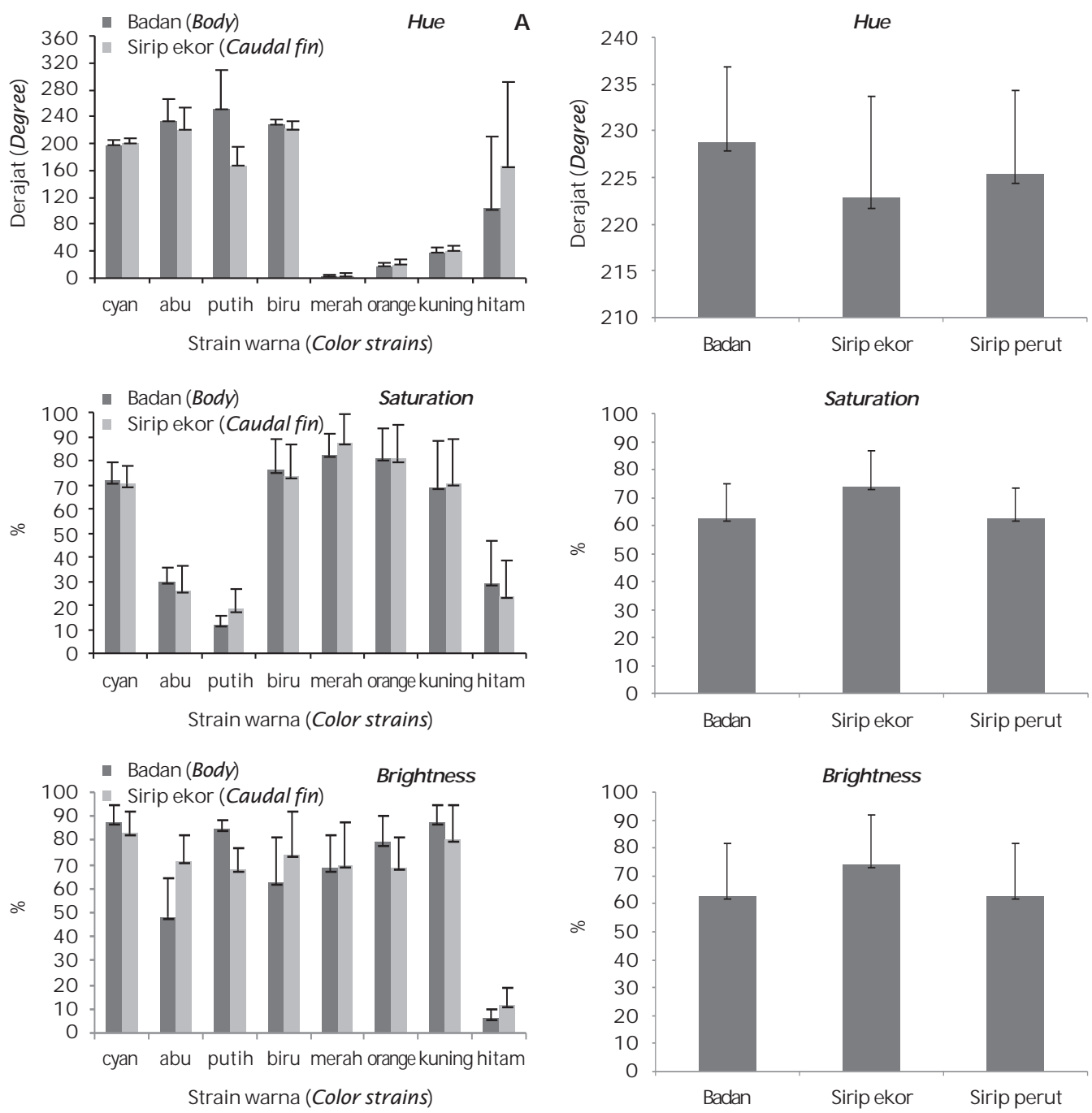

Gambar 4. (A) Perbandingan karakter warna HSB badan dan sirip ekor pada setiap strain warna ikan cupang hias (Betta splendens); (B) Perbandingan karakter warna HSB pada badan, sirip ekor, dan sirip perut dalam strain warna biru

Figure 4. (A) ratio of HSB color character of body and caudal fish of each color strain of Betta splendens; (B) ratio of HSB color character of body and caudal fin, and ventral fin of blue color strain 
badan lebih jenuh dibandingkan warna pada sirip ekornya sedang ikan cupang putih, merah, dan kuning adalah sebaliknya (Gambar 4A).

\section{Kecerahan}

Perbedaan paling besar dimiliki strain warna putih sedangkan terkecil pada strain merah. Secara lengkap disajikan pada Tabel 2 dan Gambar 4A.

\section{Dalam Suatu Strain Warna}

Pada strain ikan cupang biru, warna badan cenderung menunjukkan nilai hue $(\mathrm{H})$ lebih tinggi dibandingkan warna sirip ekor dan sirip perut namun setelah diuji statistik tidak berbeda nyata $(P>0,05)$ satu sama lainnya. Kecerahan (B) tertinggi terdapat pada sirip ekor namun tidak berbeda nyata $(P>0,05)$ dengan warna badan dan sirip perut. Secara lengkap disajikan pada Tabel 3 dan Gambar 4B.

\section{Gambar Digital}

Gambar digital (digital image) merupakan wujud numerik dari suatu gambar dua dimensi (2D) (Wikipedia, 2011) yang dihasilkan oleh perangkat elektronik atau media digital berupa kamera digital; scanner; web camera; hingga handycam. Selain menggunakan peralatanperalatan tersebut, gambar digital juga bisa dibuat dan dihasilkan dari data non-gambar (non- image), seperti fungsi matematika (kurva dan polygon) dan model geometri tiga dimensi (Wikipedia, 2011).

Gambar digital dibangun oleh unit terkecil berbentuk titik (dot) atau persegi empat (square) yang disebut piksel (pixel, picture element) (Gambar 5). Setiap piksel tersusun secara horizontal maupun vertikal menempati setiap ruang dimensi gambar serta memiliki nilai- nilai digital dari suatu jenis warna tertentu ( 1 piksel $=1$ jenis warna). Berdasarkan nilainilai inilah warna- warna yang muncul pada gambar digital selanjutnya dapat diukur,

Tabel 3. Pengukuran komponen warna HSB pada badan, sirip ekor, dan sirip anal dalam strain ikan cupang hias warna biru

Table 3. Measured HSB color component on body, caudal fin, and anal fin in blue color strain of siamese fighting fish

\begin{tabular}{lccc}
\hline $\begin{array}{c}\text { Bagian tubuh } \\
\text { Component of body }\end{array}$ & H (')* & S (\%)* & B (\%) \\
\hline Badan (Body) & $229 \pm 8^{\mathrm{a}}$ & $76 \pm 12^{\mathrm{a}}$ & $63 \pm 19^{\mathrm{a}}$ \\
Sirip ekor (Caudal fin) & $223 \pm 11^{\mathrm{a}}$ & $74 \pm 13^{\mathrm{a}}$ & $74 \pm 18^{\mathrm{a}}$ \\
Sirip perut (Anal fin) & $225 \pm 9^{\mathrm{a}}$ & $76 \pm 11^{\mathrm{a}}$ & $63 \pm 19^{\mathrm{a}}$ \\
\hline
\end{tabular}

* Nilai digital HSB (Mean + SD), warna biru di badan, sirip ekor, dan sirip perut tidak berbeda nyata $(\mathrm{P}>0,05)$ pada setiap komponen warna $(\mathrm{H}, \mathrm{S}, \mathrm{B})$ / Digital values of HSB (Mean $+S D)$, blue color on body, caudal fin, and anal fin are not significantly different $(P>0.05)$ on each color components $(H, S, B)$

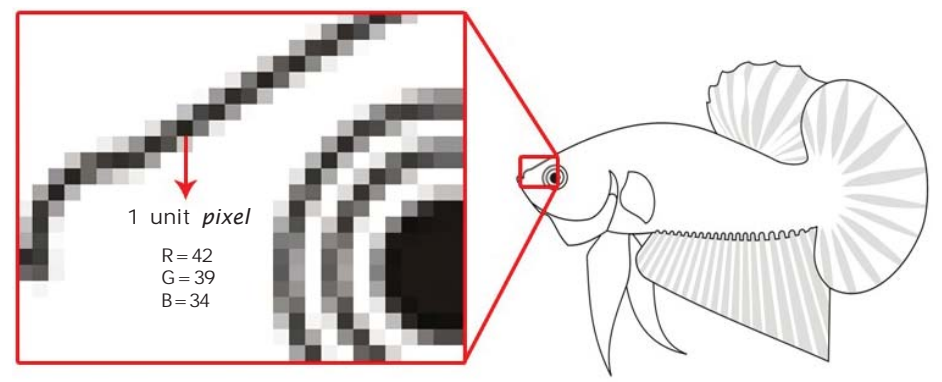

Gambar 5. Piksel dan nilai digital suatu warna

Figure 5. Pixel and digital value of color 
dikontrol, atau bahkan dimanipulasi. Dengan bantuan software seperti ImageJ, warna- warna yang ditampilkan oleh setiap piksel selanjutnya dapat dikarakterisasi dan dikuantifikasi.

\section{Model Warna Digital}

Model warna digital atau lebih dikenal dengan istilah color space merupakan perwujudan warna dari fungsi matematika yang membangun suatu gambar digital. Model warna terbagi dua, yaitu tipe yang berdasarkan atas percampuran warna dasar cahaya (RGB) dan tipe yang jenis warna serta kecerahannya terpisah (HSB) (FuZhong dalam YongYue et al., 2009).

\section{RGB}

Salah satu jenis warna yang ditampilkan oleh setiap piksel pada gambar digital adalah model RGB (Red Green Blue). RGB dibuat mengikuti pengembangan konsep penyebaran warna primer cahaya (merah, hijau, biru) setelah melewati kristal berbentuk prisma, ini selanjutnya dimanfaatkan pada banyak perangkat elektronik berbasis visual, seperti televisi dan monitor komputer.

Warna- warna yang muncul pada model warna RGB (Red Green Blue) dihasilkan dari percampuran tiga komponen warna primer cahaya (merah (R), hijau (G), dan biru (B)). Setiap nilai yang dihasilkan memberikan pengaruh terhadap warna- warna yang muncul. Konsep warna RGB yang terbentuk secara lengkap tersaji pada Tabel 4.

\section{HSB}

Nilai hue $(\mathrm{H})$ menunjukkan jenis warna dalam derajat $\left(0^{\circ}-360^{\circ}\right)$; saturation (S) menunjukkan tingkat kejenuhan bernilai persen (\%), dan brightness menunjukkan nilai kecerahan (B) bernilai persen (\%). Warna merah murni akan muncul jika memiliki nilai $\mathrm{H}=0 \% 360^{\circ} ; \mathrm{S}=100 \%$ dan $B=100 \%$ Secara lengkap konsep warna HSB disajikan pada Tabel 5.

\section{Karakterisasi dan Kuantifikasi Warna}

Setiap strain warna yang tampak secara visual pada badan dan sirip ikan cupang hias (Betta splendens) dapat dikarakterisasi dan dikuantifikasi secara objektif berdasarkan standar nilai RGB (Tabel 1; Gambar 2) maupun HSB (Tabel 2; Gambar 3). Setiap strain warna memiliki variasi nilai RGB dan HSB yang berbeda dan spesifik untuk menampilkan jenis- jenis warna (Tabel 1 dan 2; Gambar 2 dan $3)$.

Tabel 4. Konsep nilai digital RGB dari setiap jenis warna

Table 4. Digital value concept of RGB from each strain color

\begin{tabular}{ccccccccccccc}
\hline $\begin{array}{c}\text { Komponen } \\
\text { Component }\end{array}$ & $\begin{array}{c}\text { Kisaran } \\
\text { Range }\end{array}$ & $\begin{array}{c}\text { Merah } \\
\text { Red }\end{array}$ & $\begin{array}{c}\text { Kuning } \\
\text { Yellow }\end{array}$ & $\begin{array}{c}\text { Hijau } \\
\text { Green }\end{array}$ & $\begin{array}{c}\text { Cyan } \\
\text { Cyan }\end{array}$ & $\begin{array}{c}\text { Biru } \\
\text { Blue }\end{array}$ & $\begin{array}{c}\text { Magenta } \\
\text { Magenta }\end{array}$ & $\begin{array}{c}\text { Hitam } \\
\text { Black }\end{array}$ & $\begin{array}{c}\text { Abu } \\
\text { Grey }\end{array}$ & $\begin{array}{c}\text { Putih } \\
\text { White }\end{array}$ \\
\hline R & $0-255$ & 255 & 255 & 0 & 0 & 0 & 255 & 0 & $1-254$ & 255 \\
G & $0-255$ & 0 & 255 & 255 & 255 & 0 & 0 & 0 & $1-254$ & 255 \\
B & $0-255$ & 0 & 0 & 0 & 255 & 255 & 255 & 0 & $1-254$ & 255 \\
\hline
\end{tabular}

* Komponen R (Merah), G (Hijau), dan B (Biru) selalu bernilai sama (Component R (Red), G (Green), and B (Blue) same value always)

Tabel 5. Konsep nilai digital HSB dari setiap jenis warna

Table 5. Digital value concept of HSB from each strain color

\begin{tabular}{cccccccccccccc}
\hline $\begin{array}{c}\text { Komponen } \\
\text { Component }\end{array}$ & $\begin{array}{c}\text { Kisaran } \\
\text { Range }\end{array}$ & $\begin{array}{c}\text { Merah } \\
\text { Red }\end{array}$ & $\begin{array}{c}\text { Kuning } \\
\text { Yellow }\end{array}$ & $\begin{array}{c}\text { Hijau } \\
\text { Green }\end{array}$ & $\begin{array}{c}\text { Cyan } \\
\text { Cyan }\end{array}$ & $\begin{array}{c}\text { Biru } \\
\text { Blue }\end{array}$ & $\begin{array}{c}\text { Magenta } \\
\text { Magenta }\end{array}$ & $\begin{array}{c}\text { Hitam } \\
\text { Black }\end{array}$ & $\begin{array}{c}\text { Abu } \\
\text { Grey }\end{array}$ & $\begin{array}{c}\text { Putih } \\
\text { White }\end{array}$ \\
\hline H (\%) & $0-360$ & $0 / 360$ & 60 & 120 & 180 & 240 & 300 & $0-360$ & $0-360$ & $0-360$ \\
$\mathbf{S ~ ( \% ) ~}$ & $0-100$ & 100 & 100 & 100 & 100 & 100 & 100 & 0 & 0 & 0 \\
B (\%) & $0-100$ & 100 & 100 & 100 & 100 & 100 & 100 & 0 & $1-99$ & 100 \\
\hline
\end{tabular}

H (Hue), S (Saturation), B (Brightness) 
Model warna RGB lebih sulit dipahami karena setiap warna saling bergantung dari hasil percampuran atas ketiga komponen warna (Red, Green, dan Blue) (Tabel 4). Dengan kata lain, setiap warna dipengaruhi setiap komponen atau tidak berdiri sendiri (bebas). Sedangkan model warna HSB memiliki komponen (Hue, Saturation, Brightness) yang tidak saling bergantung antara satu sama lainnya. Jenis warna ditentukan nilai hue $(\mathrm{H})$, kemurnian atau kejenuhan warna ditentukan nilai saturation (S), sedangkan kecerahan ditentukan oleh nilai brightness (B) sehingga mudah dipahami sesuai konsep cara pandang mata manusia. Mata dapat melihat berbagai jenis warna (Hue). Sedangkan kualitasnya ditentukan oleh tingkat kecerahan (B) serta kemurnian (S)- nya. Semua jenis warna akan tampil berwarna hitam (gelap pekat) jika tingkat kecerahan (B)- nya bernilai 0\% sebaliknya, setiap jenis warna akan tampil berwarna putih jika tingkat kecerahan (B)- nya bernilai 100\% dan tingkat kejenuhan (S)- nya bernilai 0\% (Tabel 5). Berdasarkan hal tersebut, kualitas warna, seperti halnya kecerahan (B), akan lebih mudah dikuantifikasi berdasarkan model warna HSB.

\section{Aplikasi Metode Analisis Warna}

Analisis warna berperan penting dalam banyak bidang penelitian. Byers (2006),
Pavlidis et. al. (2006), serta Chapman \& FitzCoy dalam Yasir \& Qin. (2009) menggunakannya dalam bidang taksonomi; Hoekstra (2006) dan Hofreiter \& Schoneberg (2010) dalam bidang evolusi; Clotfelter et al. (2007) dalam bidang kesehatan hewan; Szisch et al. (2002) dan Yasir \& Qin (2009) dalam bidang fisiologi; Booth et al. (2004) dan Kalinowski et al. (2005) dalam bidang nutrisi. Selain itu, berbagai ilmu lainnya seperti genetika kuantitatif (David et al., 2004) dan tingkah laku hewan (etologi) (Korzan et al., 2008; Price et al., 2008) seringkali juga menggunakan karakter warna hewan sebagai bahan dan objek penelitian.

\section{ImageJ dan Grafis}

Image merupakan software berbasiskan bahasa program Java yang dikembangkan oleh National Institutes of Health, USA untuk memproses ataupun analisis gambar digital (image processing). ImageJ dibangun berdasarkan kepemilikan umum (public domain) dan dapat diunduh secara gratis dari alamat http://rsb.info.nih.gov. Selain menyajikan informasi dalam bentuk nilai (angka), software Image juga mampu menampilkan informasi dalam bentuk grafis dua dan tiga dimensi (Gambar 6 dan 7). Distribusi dua dimensi (Gambar 6) menunjukkan pada kita di mana lokasi puncak berbagai komponen warna R, G, dan B suatu gambar digital.
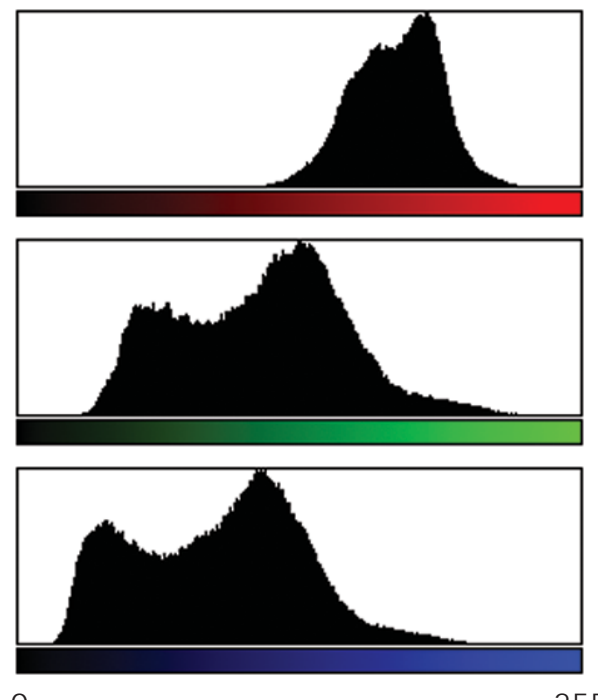

0
Count: 319704

rMean: 171.55

gMean: 109.99

bMean: 90.47

rSD: 19.70

gSD: 38.22

bSD: 38.20

rMode: 186

gMode: 128

bMode: 112

Gambar 6. Distribusi warna dalam grafis dua dimensi untuk model warna RGB

Figure 6. Color distribution in two dimension graphic for RGB color model 

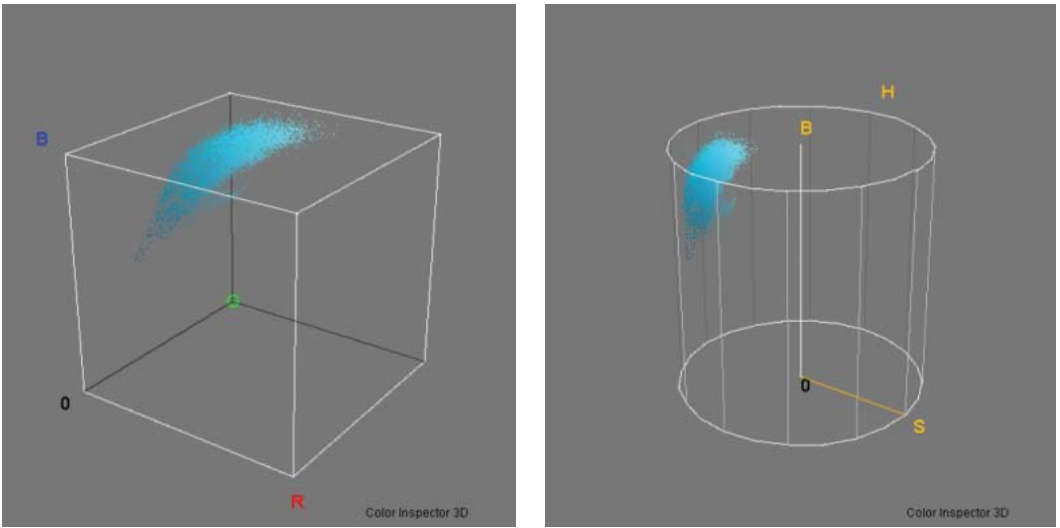

Gambar 7. Distribusi warna suatu individu strain cupang cyan dalam grafis tiga dimensi untuk model warna RGB dan HSB

Figure 7. Color distribution of Betta cyan strain in $3 D$ graphic for RGB and HSB color model

\section{KESIMPULAN}

Analisis gambar digital dengan bantuan software merupakan metode alternatif karakterisasi warna pada ikan hias yang murah, aplikatif, obyektif, serta akurat. Warna- warna yang terlihat dan tertangkap langsung oleh mata (visual) dapat dikuantitatifkan berdasarkan standar nilai RGB (Red Green Blue) dari setiap pikselnya. Nilai ini dapat dikonversi ke dalam model HSB (Hue Saturation Brightness) sehingga lebih mudah dipahami. Beberapa parameter warna mulai dari kisaran; mean; standar deviasi (SD); persentase dapat diukur dengan mudah. Nilai HSB dapat dianalisis secara statistika untuk menguji perbedaan kualitas warna. Selain tersaji dalam bentuk nilai, data yang terukur juga dapat ditampilkan dalam bentuk grafis berupa histogram dua dimesi maupun tiga dimensi. Beberapa software analisis warna, seperti ImageJ, tersedia secara gratis, dan dapat diunduh langsung dari situsnya masingmasing.

\section{UCAPAN TERIMA KASIH}

Penulis mengucapkan terima kasih kepada tim peneliti dan seluruh teknisi Balai Riset Budidaya Ikan Hias Depok, dan semua pihak yang membantu kegiatan ini dan Saudara Sutrisno (Betta Mania Independen Indonesia) untuk koleksi foto beberapa strain warna ikan cupang.

\section{DAFTAR ACUAN}

Ako, H., Tamaru, C.S., Asano, L., Yuen, B., \& Yamamoto, M. Achieving natural coloration in fish under culture. UJNR Technical Report, 28: 4.

Anderson, S. 2000, Salmon Color and the Consumer. IIFET 2000 Proceedings, $3 \mathrm{pp}$.

Barthel, K.U. 2007. Color Inspector 3D. http:// rsbweb.nih.gov/ij/plugins/colorinspector.html. diakses Tanggal 13 Juni 2011 pukul 10:29.

Booth, M.A., Warner- Smith, R.J., Allan, G.L., \& Glencross, B.D. 2004. Effects of dietary astaxanthin source and light manipulation on the skin colour of Australian snapper Pagrus auratus (Bloch \& Schneider, 1801). Aquaculture Research, 35: 458- 464.

Byers, J.A. 2006. Analysis of Insect and Plant Colors in Digital Images Using Java Software on the Internet. Ann. Entomol. Soc. Am., 99(5): 865- 874.

Clotfelter, E.D., Ardia, D.R., \& McGraw, K.J. 2007. Red fish, blue fish: trade- offs between pigmentation and immunity in Betta splendens. doi:10,1093/beheco/arm090. Behavioral Ecology, p. 1,139- 1,145.

Colihueque, N. 2010, Genetics of salmonid skin pigmentation: clues and prospects for improving the external appearance of farmed salmonids. Rev. Fish Biol. Fisheries, 20: 7186. 
David, L., Rothbard, S., Rubinstein, I., Katzman, H., Hulata, G., Hillel, J., \& Lavi, U. 2004. Aspects of red and black color inheritance in the Japanese ornamental (Koi) carp (Cyprinus carpio L.). Aquaculture, 233: 129147.

Hofreiter, M. \& Schoneberg, T. 2010. The genetic and evolutionary basis of colour variation in vertebrates. Cellular and Molecular Life Sciences, 67: 2,591-2,603.

Hoekstra, H.E. 2006. Genetics, development and evolution of adaptive pigmentation in vertebrates: short review. Heredity, 97: 222-234.

Kalinowski, C.T., Robaina, L.E., FernandezPalacios, H., Schuchardt, D., \& Izquierdo, M.S. 2005. Effect of different carotenoid sources and their dietary levels on red porgy (Pagrus pagrus) growth and skin colour. Aquaculture, 244: 223- 231.

Korzan, W.J., Robison, R.R., Zhao, S., \&Fernald, R.D. 2008. Color change as a potential behavioral strategy. Hormones and Behavior 54 (2008) 463-470, doi:10,1016/ j.yhbeh.2008.05.006.

Leclercq, E., Taylor, J.F., \& Migaud, H. 2009. Morphological skin colour changes in teleosts. Fish And Fisheries. 1-35. DOI: 10,1111/j.1467-2979.2009.00346.x.

Pavlidis, M., Papandroulakis, N., \& Divanach, P. 2006. A method for the comparison of chromaticity parameters in fish skin: Preliminary results for coloration pattern of red skin Sparidae. Aquaculture, 258: 211- 219.
Price, A.C., Weadick, C.J., Shim, J., \& Rodd, F.H. 2008. Pigments, Patterns, and Fish Behavior. Zebrafish, 5(4)

Tume, R.K., Sikes, A.L., Tabrett, S., \&Smith, D.M. 2009. Effect of background colour on the distribution of astaxanthin in black tiger prawn (Penaeus monodon): Effective method for improvement of cooked colour. Aquaculture, 296: 129- 135.

Thompson, A.W. 1910, Translated online of Historia Animalium (Aristotle, 350 SM). http:/ / classics.mit.edu// Aristotle/ history_anim.html. diakses 20 September 2010 pukul 8:44:57 AM.

Szisch, V., van der Salm, A.L., Bonga, S.E.W., \& Pavlidis, M. 2002. Physiological colour changes in the red porgy, Pagrus pagrus, following adaptation to blue lighting spectrum. Fish Physiology and Biochemistry, 27: 1-8.

Wikipedia. 2011. Digital image. http:// e n.wiki pedia.org/wiki/ Digital image?oldid=0. diakses 1 Juni 2011 pukul 10:46.

Yasir, I. \& Qin, J.G. 2009. Effect of Light Intensity on Color Performance of False Clown fish, Amphiprion ocellaris Cuvier. J. Of The World Aquaculture Society, 40(3): 337- 350.

YongYue, C., HuiPing, Z., \& HuoSong, X. 2009. A Study on the Algorithm Based on Image Color Correlation Mining. International J. of Computer Information Systems and Industrial Management Applications (IJCISIM), 1: 279- 286. 